\title{
CHROMOFORE POLING IN THIN FILMS OF ORGANIC GLASSES. 1. OVERVIEW OF CORONA DISCHARGE APPLICATION
}

\author{
O. Vilitis, E. Fonavs, M. Rutkis \\ Institute of Solid State Physics, University of Latvia, \\ 8 Ķengaraga Str., Riga, LV-1063, LATVIA
}

\begin{abstract}
The introductory article in a series of works on the chromofore poling in thin films of organic glasses presents an overview of corona discharge applications, with a brief excursion into physics of the phenomenon. The authors consider this technique as related to the nonlinear optical (NLO) polymers. Its key points are as follows.

In the ambient air such discharge is strongly affected by variable humidity and, consequently, uncertain concentration of the predominant charge carrier $\left(\left(\mathrm{H}_{2} \mathrm{O}\right)_{\mathrm{n}} \mathrm{H}^{+}\right)$. To realize a repeatable poling process the composition of discharge atmosphere should be controlled (e.g. for pure nitrogen gas). In the case of discharge in $\mathrm{N}_{2}$ the highly reactive ozone production could be avoided. To obtain second-order nonlinear activity of polymeric materials, a simple point/plane (two-electrode) technique of corona charging is successfully applied, which however does not provide information about the sample surface charge buildup and the efficiency of poling process. To study the dynamics of both the poling and the charge transport processes a three-electrode charging system - the corona triode - should be used.
\end{abstract}

Key words: corona discharge, corona poling, $N L O$ polymer.

\section{INTRODUCTION}

Over the last two decades a growing attention of investigators is attracted to the use of organic molecular materials in a wide variety of nonlinear optical (NLO) applications. Most important among them are extra-high speed electro-optic modulators, where employment of organic materials can eliminate existing physical speed restrictions of nowadays used inorganic materials [1]. From technological point of view promising are polymers and low molecular organic materials capable of forming amorphous phase or so-called organic glasses. Such NLO materials are typically built from two functional units, one of them being responsible for glassy state formation while another (chromophore) - for NLO properties. As made, amorphous organic glasses are centrosymmetric and NLO inactive, because the orientation distribution of chromophores is random. To act in an NLO material, these polar moieties must be acentrically aligned (poled), which is generally achieved by applying electric poling field. The magnitude of the nonlinear susceptibility of the material is dependent on the degree of chromophore alignment and, therefore, on the poling field strength. One of the possibilities to achieve a high magnitude of the poling field is charging of the thin film surface by corona discharge. 
With this contribution we are starting a series of articles committed to chromophore poling in thin films of organic glasses. The first part of this introductory article is devoted to corona discharge physics, and the second part is overview of the methods and techniques used for corona poling in thin organic films.

\section{THE PHENOMENON OF CORONA DISCHARGE}

Corona ("crown") discharge is a self-sustained non-disruptive electrical discharge. In a medium, for instance, air, this occurs at the atmospheric pressure when a sufficiently high voltage is applied to the electrodes and the electric field in the discharge gap is strongly inhomogeneous, which is caused by a small surface curvature of the radius of one or both electrodes (sharp points, edges, or wires). At high enough corona currents and under low ambient light the corona discharges are luminous, visible as a blue or bluish-white glow. Sailors for ages have observed the discharges between the masts of their ships and the dark clouds of approaching storm. The frightened seamen interpreted the blue glow around the mast tops as a sign of protection from Saint Elmo, the patron of sailors. Benjamin Franklin was the first who, in 1749, correctly related the "St. Elmo's fire" to atmospheric electricity. Many famous poets and writers, William Shakespeare among them (see "Tempest", act 1, scene 2), have mentioned the splendid phenomenon.

In a typical corona poling setup a corona discharge is attained between a conducting planar electrode and another electrode - a sharp needle or a thin wire of 5-20 $\mu \mathrm{m}$ radius placed at a distance of one to several $\mathrm{cm}$ from it. If the voltage between the electrodes is gradually increased from zero, a weak current grows exponentially in the circuit. The current is supported by ions swept out of the wire along its axis and by electrons created by ionising background radiation (cosmic rays or other sources). Under the applied electric field the carriers migrate to the electrodes of two-electrode system, creating a current (usually $<1 \mathrm{pA}$ ). At further increase in the applied voltage eventually all available charge carriers are swept away, the current saturates and remains constant over a wide range of voltage. The current is a linear function of the strength of radiation source - a mode useful for some radiation counters. Continuing to increase the potential between electrodes we initiate the so-called Townsend discharge and the current rises exponentially again. Now the electric field becomes strong enough to provide initially present in the air electrons, with the energy necessary to ionise neutral atoms before they reach the corona electrode. As the electric field becomes even stronger, the secondary electrons may ionise other neutral atoms resulting in an avalanche production of electrons and ions.

At the corona onset the current increases by about six orders of magnitude [2]. At low currents the corona discharge is dark. It is accompanied by a glow when the current is strong enough. The range from zero up to the breakdown potential on the current-voltage diagram is called the dark discharge, because, except for the corona discharge, it remains invisible. Ionisation of gas proceeds only within a thin layer in the immediate vicinity of electrodes with a small curvature radius where electric field is the strongest. The layer within which the ions and electrons are produced is called the corona region or corona plasma region. In this region, the electric field is strong enough to supply electrons with 
the energy necessary for ionising collisions in the gas. The corona is referred to as positive or negative, depending on the polarity of the electrically-stressed electrode - the "corona electrode". The positive corona discharge differs from the negative one by the generation mechanism. While the former has usually a diffuse and uniform glow, the negative corona discharge is a localised "tuft" or "brush" discharge at the corona electrode. The light produced by discharge is not due to ionisation but to excitation and subsequent release of excess energy in the form of light and other electromagnetic waves. The species with the lowest ionisation potential will normally appear in the highest concentration when corona discharge is proceeding. In the air the negative coronas mainly generate $\mathrm{CO}_{3}{ }^{-}$ions, whereas the $\left(\mathrm{H}_{2} \mathrm{O}\right)_{n} \mathrm{H}^{+}$ions (hydrated protons) are predominant in the positive corona $[3,4]$. A corona discharge also produces activated species, such as ozone and other gaseous products including $\mathrm{O}, \mathrm{N}, \mathrm{N}_{2} \mathrm{O}, \mathrm{NO}_{2}, \mathrm{NO}_{3}, \mathrm{~N}_{2} \mathrm{O}_{5}, \mathrm{O}_{2} *$, and $\mathrm{N}_{2} *$ [5].

Hereafter, we shall be interested in considering the direct current (DC) unipolar positive corona discharge [6] in air at atmospheric pressure. In this case, the positive pole of a 5-12 kV voltage source is connected to "corona electrode" of the discharge setup and the negative - to the collection electrode placed at a distance from the corona electrode (further referred to as the "opposite electrode").

Apart from electron and ion generation in the corona plasma region, there is another important process of corona discharge - transfer of ions from the plasma surrounding the wire to the opposite electrode. This plasma region is called the outer corona discharge or unipolar ion region, where the electric field is not strong enough to cause ionisation of gas and the positive ions' drift along the electric field towards the opposite - negative electrode. Corona discharge current is limited by positive space charge of the ion current carriers forming up in the region of strong electric field. This space charge forms up its own electric field, which decreases the electric field in the part of outer corona discharge region nearby the corona electrode (the screening effect). Due to this space charge the electric field distribution in the outer corona discharge region is changed, and the corona discharge current is proportional to the applied voltage squared [7] (see later). Hereto, the discharge process stabilises. As the applied voltage increases, the corona discharge current grows until the breakdown or sparking potential is reached. An increase in the current by factor of $10^{4}$ to $10^{8}$ follows, and usually only the internal resistance of the power supply connected to the electrodes limits this current. In the setups of a two-electrode system for poling thin polymeric films the onset corona discharge mode is usually chosen, and the current does not exceed 1-3 $\mu \mathrm{A}$. The current in this region is chosen based on optimisation of the second harmonic generation (SHG) signal [8]. Higher voltages and corresponding corona discharge currents damage the sample surface and do not increase substantially the efficiency of molecular orientation. The threshold of corona discharge onset is determined by the electric field intensity $E_{c}$ at the corona electrode sufficient to cause ionising collisions in the actual gas (e.g., air) species. The field $E_{c}$ is assumed to be equal to the value given by F.W. Peek's semi-empirical dimensional formula for the corona initiation electric field (or the corona onset field) in air for concentric cylinders [9]:

$$
E_{c}=g_{o} \cdot \delta \cdot m\left(1+\frac{0.308}{\sqrt{\delta \cdot r}}\right), \frac{\mathrm{kV}}{\mathrm{cm}},
$$


where $g_{o}=31 \mathrm{kV} / \mathrm{cm}$ is the voltage gradient constant;

$m$ is a dimensionless roughness parameter of the surface of wire electrode ( $m=1$ for a polished wire);

$r$ is the wire radius in $\mathrm{cm}$;

$\delta$ is the relative density of air defined at $298{ }^{\circ} \mathrm{K}, \delta=\frac{T_{o} \cdot p}{T \cdot p_{o}}$;

$T_{o}$ is the reference temperature of $298^{\circ} \mathrm{K}$;

$T$ is the actual temperature of the air in ${ }^{\circ} \mathrm{K}$,

$p_{o}$ is the reference atmospheric pressure of air equal to $76 \mathrm{~cm}$,

$p$ is the actual barometric pressure in $\mathrm{cm}$.

Expressing temperature $t$ in ${ }^{\circ} \mathrm{C}$ and simplifying the $\delta$ ratio we will obtain:

$$
\delta=\frac{(273+25) p}{(273+t) 76} \approx \frac{3.92 p}{273+t} .
$$

At barometric pressure $p=76 \mathrm{~cm}$ and temperature $t=25^{\circ} \mathrm{C}, \delta=1$.

The assumption that the electric field intensity at the wire is equal to Peek's onset field intensity at the wire is justified by Morrow [10]. In the case the discharge between the corona wire and a planar opposite electrode occurs, Eq. (1) may be used $[11,12]$.

Under the condition that the doubled distance between the corona wire and the parallel planar opposite electrode is $2 h \gg>r$, the maximum field around the wire is:

$$
E_{\max } \approx \frac{V}{r \cdot \ln \frac{2 h}{r}},
$$

where $V$ is the voltage between electrodes.

The expression follows from solution of the corresponding electrostatic problem [11].

For $E_{\max }=E_{c}$ and $V=V_{c}$ we will write:

$$
V_{c}=E_{c} \cdot r \cdot \ln \frac{2 h}{r} \text {. }
$$

$V_{c}$ is the corona initiation (corona onset) voltage in $\mathrm{kV} /$ the voltage at which the corona discharge begins.

With account of (1)-(3),

$$
V_{c}=r \cdot \ln \left(\frac{2 h}{r}\right) \cdot \frac{3.92 p \cdot g_{o}}{273+\mathrm{t}} \cdot \frac{0.308}{\sqrt{\frac{3.92 p \cdot r}{273+\mathrm{t}}}}, \mathrm{kV},
$$

$r, h$, and $p$ are in $\mathrm{cm}, g_{o}-$ in $\mathrm{kV} / \mathrm{cm}$, and temperature $t-$ in ${ }^{\circ} \mathrm{C}$.

As the applied voltage reaches value $V_{c}$, the air surrounding the wire will start to become ionised and thus conductive. At that point, the effective radius of wire increases since the air is acting like a conductor. Equation (4) indicates that the voltage gradient around the wire changes with the change in the effective 
radius. If this gradient decreases with the increase in the effective radius, the corona discharge will form. At the critical corona onset voltage, the ionisation and excitation of electronic states are reached. This is exemplified in Figs. 1 and 2 for corona onset field $E_{c}$ and corona initiation voltage $V_{c}$ as functions of the actual air temperature $t$ calculated from expressions (1) and (4) at $p=76 \mathrm{~cm}, r=0.0012 \mathrm{~cm}$, and $h=1 \mathrm{~cm}$.

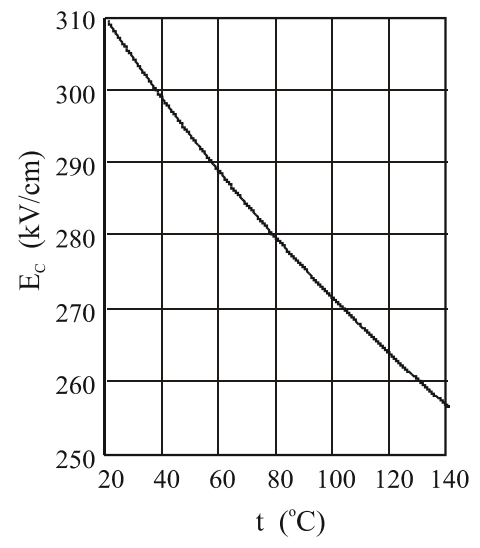

Fig 1. Corona onset field as a function of the actual temperature of air.

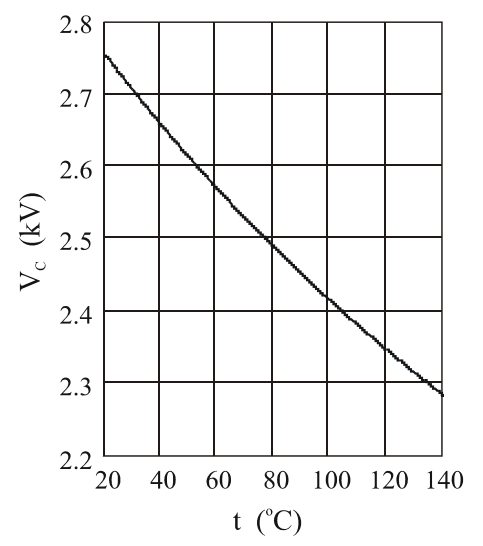

Fig. 2. Corona initiation voltage as a function of the actual temperature $t$ of air.

Dependence of corona initiation voltage $V_{c}$ (4) of corona wire radius $r$ at $h=1 \mathrm{~cm}, g_{o}=31 \mathrm{kV} / \mathrm{cm}, t=20^{\circ} \mathrm{C}$, and $p=76 \mathrm{~cm}$ is illustrated in Fig. 3. At small radii the initiation voltage of a negative corona is approximately the same as of a positive one.

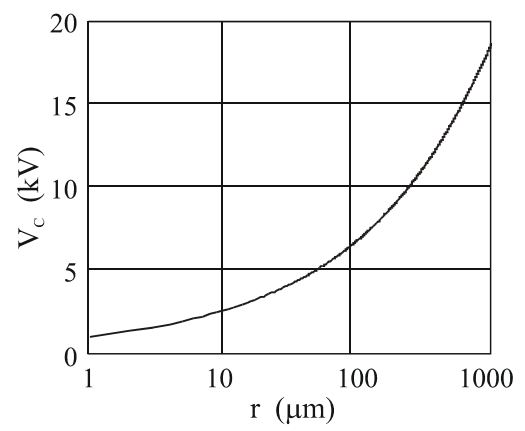

Fig. 3. Corona discharge initiation voltage as a function of the corona wire radius.

At the scale of corona discharge the plasma surrounding the corona wire is very small. The avalanche multiplication of secondary electrons and excitation of gas molecules surrounding the corona wire fades off at the distance at which the field intensity drops below $E_{1} \approx 24 \mathrm{kV} / \mathrm{cm}$ [10]. For example, at the wire radius $r=0.0012 \mathrm{~cm}$ the corona onset field is $E_{c}=2.6 \mathrm{kV} / \mathrm{cm}$, and the thickness of corona layer is:

$$
x \approx r\left(\frac{E_{c}}{E_{1}}-1\right)=0.0012\left(\frac{2.6}{2.4}-1\right)=10^{-4} \mathrm{~cm} .
$$


The current through the outer corona region determines the current of corona discharge. To obtain the current-voltage characteristic $i(V)$ it is necessary to express the space charge density in terms of current and ion mobility, and solve the Poisson equation for the outer corona region. In the simplest case - a coaxial cylinder, the complete solution may be found $[11,12]$. However, the final expression is too complicate. For that reason in practice the approximation by classical Townsend's formula [10] for linear current density $j$ per unit length $L$ of wire is used.

Mobility $\mu$ of positive ions in air is estimated to be within the range from 2.0 to $2.2 \mathrm{~cm}^{2} / \mathrm{V} \cdot \mathrm{s}[6,13]$. It should be noticed that $\mu$ depends on the time of flight. Usually it is given for standard conditions - at $0{ }^{\circ} \mathrm{C}$ and pressure of $1 \mathrm{~atm}$. In the case of coaxial cylinder geometry the linear current density is given by:

$$
j=\frac{2 \mu \cdot \kappa_{d} \cdot V}{R^{2} \cdot \ln \frac{R}{r}}\left(V-V_{c}\right), \frac{\mathrm{A}}{\mathrm{cm}},
$$

where, besides the parameters mentioned above:

$\kappa_{d}=1.111$ is a coefficient determined by the condition for dimensionality $1 \mathrm{~A}=0.9 \cdot 10^{12} \mathrm{~V} \mathrm{~cm} / \mathrm{s}$,

$R$ is the radius of outer cylinder (the opposite electrode) in $\mathrm{cm}$,

Expression (5) is in good agreement with experimental results. The parabolic form of function (5) $j=s \cdot V\left(V-V_{c}\right)$ with different $s$ values is often used for approximation of the current-voltage characteristics for different more complicated electrode configurations [7, 13, 14]. Thus, for example, if a wire of radius $r$ is placed parallel to a plane at distance $h$, the linear current density per unit length of the wire, under condition $V>V_{c}$, is approximated as [12]:

$$
j=\frac{\kappa \cdot \mu \cdot V\left(V-V_{c}\right)}{h^{2} \cdot \ln \frac{2 h}{r}}, \frac{\mu \mathrm{A}}{\mathrm{cm}^{2}} .
$$

As previously, $r$ and $h$ are in $\mathrm{cm}, V$ and $V_{c}-$ in $\mathrm{kV}$, and $\mu-$ in $\mathrm{cm}^{2} / \mathrm{V} \mathrm{s}$.

The geometry-dependent empirical constant $\kappa=0.78$ determines the slope of parabolic curve.

In this case, compared with Eq (5), the radius of cylindrical opposite electrode is replaced by the equivalent cylinder radius $2 h$. Practically $[8,15]$, the corona electrode with such wire configuration is consistently used to produce polymer NLO films with high-quality poled rectangular area whose width is approximately equal to the doubled distance between the corona wire and the polymer layer, and the area length is equal to that of wire. Equation (6) is a rough approximation of positive DC corona discharge characteristic $i(V)$ under the condition that an open corona wire is parallel to the planar opposite electrode. Full $i(V)$ relationship in the case of a thin wire and a wide plate, with account for (1) and (4), is given as 


$$
i=\frac{\kappa \cdot \mu \cdot L \cdot V}{h^{2} \cdot \ln \frac{2 h}{r}}\left[V-r \cdot \ln \left(\frac{2 h}{r}\right) \cdot \frac{3.92 \cdot 31 p}{273+t}\left(1+\frac{0.308}{\sqrt{\frac{3.92 p \cdot r}{273+t}}}\right)\right], \mu \mathrm{A},
$$

where $L$ is the length of corona wire.

As an example, the results of numerical calculations according to (7) for two different temperatures $t_{1}=20{ }^{\circ} \mathrm{C}$ and $t_{2}=150{ }^{\circ} \mathrm{C}$ are shown in Fig. 4 obtained in the case when positive DC corona discharge is modelled for an open wire of length $L=1 \mathrm{~cm}$ and radius $r=0.0012 \mathrm{~cm}$ placed parallel to a wide plate at distance $h=1 \mathrm{~cm}$, other parameters being $\kappa=0.78, \mu=2 \mathrm{~cm}^{2} / \mathrm{V} \mathrm{s}, p=76 \mathrm{~cm}$.

Comparing two curves of Fig. 4 it is seen that at a constant voltage of $V=4 \mathrm{kV}$ applied to the corona discharge electrodes the corona current increases with the ambient temperature. One more illustration is provided by numerical calculations of corona discharge current $i$ (Eq. 7) as function of the air temperature in the discharge space at $V=4 \mathrm{kV}$ and the same parameter values as above (Fig. 5). As the ambient air temperature increases by $120{ }^{\circ} \mathrm{C}$, the corona discharge current increases by about $1.4 \mu \mathrm{A}$, that is, by $40 \%$.

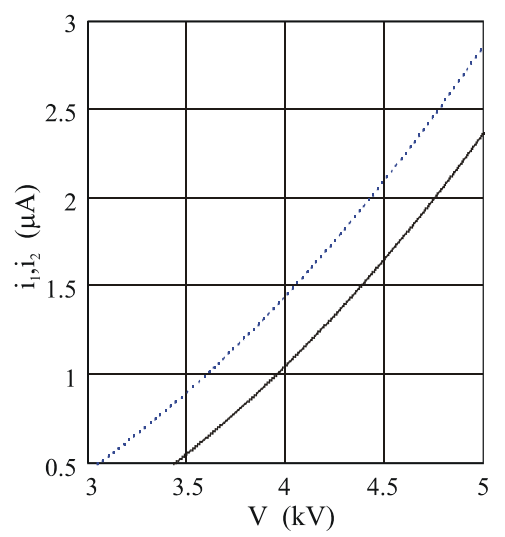

Fig. 4. Voltage-current characteristics $i_{1}(V)$ and $i_{2}(V)$ calculated for the air temperatures of $20{ }^{\circ} \mathrm{C}$ (solid curve) and $150^{\circ} \mathrm{C}$ (dotted curve).

For the corona discharge of the pin-to-plate discharge type, current/voltage curves are calculated as given in [12], i.e.:

$$
I=2 \cdot \pi \cdot K \cdot \varepsilon / \alpha \cdot[F(\delta / \alpha)]^{-2} \cdot\left(V-V_{0}\right)^{2},
$$

where $I-$ the discharge current,

$K$ - the charge carrier mobility,

$\varepsilon-$ the permittivity of medium.

$F(\delta / \alpha)$ - a series expansion of the function in terms of the ratio of the minimum curvature radius $\delta$ of corona glow at the needle and the pinto-plate distance $\alpha$.

From (8) it follows that the discharge current is proportional to the square of difference between the applied voltage and the onset voltage. 
To determine the current/voltage characteristics at various electrode geometries more precisely it is recommended to obtain them experimentally, which would not cause difficulties in the case the planar electrode is grounded. The same is true for the case of corona discharge devices with the inter-electrode air channel of discharge geometrically limited by a Teflon mask. As Ec depends on roughness, cleanliness, etc. of the wire, such an approach allows more accurate evaluation and estimation of Ec from experimental current/voltage curves $[11,13]$. If necessary, the wire-to-plane corona discharge can be modelled accurately enough [16].

\section{METHODS AND TECHNIQUES FOR POSITIVE CORONA POLING OF POLYMERIC THIN FILMS}

Originally, the direct contact electrodes were used for non-linear polymer orientation [17, 18]. However, the orienting fields achievable with electrodes deposited on the surface of thin film samples are considerably lower than the breakdown voltage of polymer [19]. In the case of parallel plate orientation the direct contact electrodes cause a high lateral conductivity on the surface of polymer film. Due to conductivity of electrodes, the energy stored in such a capacitor is available to localised spots of breakthrough where a local breakdown current through the thin insulator layer becomes destructive. The local paths of high conductivity in thin film samples (e.g., in the places of admixtures of undesirable micro-particles or ions) restrict the intensity of allowable orienting field. Electrical orientation at higher field intensities close to the dielectric breakdown voltage of thin film is possible by corona discharge $[8,17]$. A corona charging setup, as mentioned in the previous chapter, comprises a corona electrode - a thin wire of 5-20 $\mu \mathrm{m}$ radius placed parallel to a planar polymer film - the sample. Usually, the film is deposited either directly on a glass substrate, e.g., the microscope glass plate, or on the thin conductive layer previously deposited on the substrate. The layer serves as the other (opposite) electrode of corona discharge. If the polymer film is deposited on a glass substrate directly, the opposite electrode is being deposited on the other side of substrate. In this case the substrate is included in the corona discharge circuit as an element of high resistance limiting the current and reducing the effect of film surface imperfections on the allowable intensity of orienting field [8]. Usually, the resistance of PMMA is $1 \cdot 10^{16}\left(100{ }^{\circ} \mathrm{C}\right) 1 \cdot 10^{17}\left(25^{\circ} \mathrm{C}\right) \Omega \cdot \mathrm{cm}$, the specific resistance of the microscope glass plate $-5 \cdot 10^{9}\left(100{ }^{\circ} \mathrm{C}\right)-10^{12}\left(25^{\circ} \mathrm{C}\right) \Omega \cdot \mathrm{cm}[20]$. Since the substrate is $\sim 1 \mathrm{~mm}$ thick while the thickness of film is $\sim 1 \mu \mathrm{m}$, the voltage between the substrate surfaces in a corona discharge circuit is negligible compared to that on the polymer film. To start a positive corona discharge, a DC voltage close to that of the corona discharge initiation is applied between the corona wire and the opposite electrode with positive pole to the corona wire (depending on the dimensions of corona discharge space and wire radius it is between 5 and $12 \mathrm{kV}$ ).

Positive ions generated at corona discharge in a thin layer around the wire move along the force lines of electric field toward the opposite electrode. The ions are transferred from the corona region to the surface of polymer thin film where positive "electrostatic electrode" is forming up, which, in distinction from a high conductivity electrode, has low lateral conductivity [17]. Due to space charge in the outer corona discharge region the corona current is restricted by rather high corona impedance [2]. Because of that and the low lateral conductivity of "corona's 
contact", the resource of energy in direct vicinity of any point of the polymer film is small, and a local conductive path does not cause electric breakdown and destruction of the film. The intensity of electric field may be as high as $200 \mathrm{~V} / \mu \mathrm{m}$, which is close to the dielectric breakdown of thin polymer films $[8,17]$. In some cases, especially if a needle is used as the corona electrode, a metal grid is placed between the electrode and the polymer film that allows control of the orientation current, eventually achieving more homogeneous orientation $[8,21]$.

NLO polymer samples are corona poled at higher temperature to increase the mobility of non-linear components of the samples, usually above the polymer glass transition temperature $\left(T_{g}\right)$. This kind of poling will be referred to as corona-onset poling at elevated temperatures (COPET) [15]. Surface modifications of structured thin films with addition of guest molecules provide films with specific functionalities. Modified thin films have applications in many technologies, such as catalysis, electronics and biological systems.

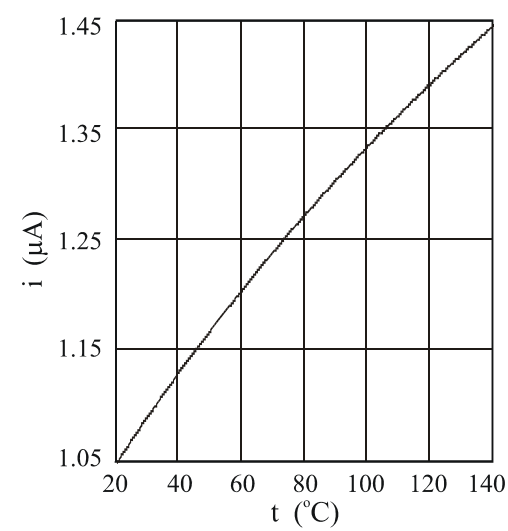

Fig. 5. Corona discharge current as a function of air temperature in the discharge space.

Glass-transition temperature $T_{g}$ of NLO host-guest polymer (HGP) materials are typically within the range from $50{ }^{\circ} \mathrm{C}$ to $140{ }^{\circ} \mathrm{C}$, in some cases up to $200{ }^{\circ} \mathrm{C}$ [8]. Samples are heated with a thermo-controlled heater thermally connected to metal, e.g., a copper block where the glass substrate with deposited films of the opposite electrode and the sample are placed. In the course of orienting the NLO polymer thin film samples, as the temperature rises up to a desirable value the current in the corona discharge circuit changes (Fig. 5), and, to maintain the optimum current mode, a gradual rise of applied high voltage is necessary. Few minutes after the orientation has begun the orientation current is observed to fall by about $20 \%$ [8]. Usually, the time during which samples are oriented at fixed elevated temperature lasts from few minutes to about $30 \mathrm{~min}$., depending on the way the polar molecules are implanted in the composite material of polymer or these molecules are chemically bounded to the polymer (see Ch. 4). After the polar molecules in the film are oriented along the applied field, the heater is turned off and the temperature is allowed to drop to the room temperature, practically within 1-2 hours. Polar molecules are "frozen" in the new orientation and the applied voltage may be turned off. The electric field in thin film samples built up during orientation is the main factor affecting the molecule orientation process. Measuring and controlling this field determines to a considerable extent the results of poling. 
Historically, in one of the first studies [22] of corona discharge current and surface potential of polymer foil electret samples a third electrode (a grid) was placed at a short distance from the sample in the corona discharge gap. The surface potential of the sample was measured by vibrating its holder in accordance with a modified Kelvin-Zisman's method [23-25], where a resistor in the discharge circuit is used for monitoring the discharge current.

Of similar design is the three-electrode corona discharge system that moreover provides possibility to maintain a constant discharge current. This is achieved through a feedback that changes supply voltage as the discharge current changes [26]. To observe dynamics of the surface potential, the Kelvin-Zisman corona triode method may be modified using the grid as the vibrating electrode $[27,28]$. The constant-current triode corona charger for polymer films [29] does not contain any vibrating elements. In this case the corona triode method is used to control by voltage-biased grid - the surface potential and ion flow to the sample [30]. When the grid voltage is controlled by means of a feedback current control circuit the charging current is maintained constant. This circuit compares the charging current from the measuring electrode with a reference signal and drives the grid voltage supply. Any deviation from a predetermined constant value of the charging current is compensated by a corresponding change of the grid voltage. If the charging current is constant, voltage $V_{\text {gap }}$ in the air gap between the grid and the sample is also constant. Assuming the $V_{\text {gap }}$ to be known [27], the grid potential is measured as a function of time $V_{g}(t)$, and during the time of orientation the surface potential of the sample $V_{s}(t)$ may be assessed from the results of measuring: $V_{s}(t)=$ $V_{g}(t)-V_{g a p}$. So the sample potential is readily determined from the grid voltage. Voltage $V_{\text {gap }}$ can be found by measuring the grid voltage at the chosen constant current value in the circuit where the sample is replaced by the opposite electrode. A similar technique of constant current corona charging has later been used for poling organic NLO thin films [31]. Temperature variations at poling affect the corona onset voltage, ion mobility, and, as a result, the $V_{\text {gap }}$ responsible for inaccuracies of the value of sample surface potential measured by this method. Versions of constant current corona triode poling setups [29-37] have been used in studies of polymer orientation, and their possible usage for poling NLO and HGP samples is still being examined [38, 39]. As far as we know, the first system for measuring potential difference across a thin insulating film during the corona discharge has been reported by Weinberg [40]. This system comprised two identical metal plates placed alongside one another under a common corona electrode, one of them used for reference while the other - as the sample holder. In the case such a differential measuring circuit is employed, the surface potential of the sample grows during corona discharge and has the same polarity as that of the corona electrode. As a result, the corona discharge current in the sample branch decreases. The method of measuring is based on compensating the current deficit in the sample branch from additional source $V_{b}$ to keep it equal to the current in the reference branch. When the currents are balanced the sample potential is equal to $V_{b}$.

\section{CONCLUSIONS}

The key points of the reported methods and techniques for chromofore poling by corona discharge as applied to the thin films of organic glasses are as follows. 
In practice, the poling of NLO polymers depends on two factors. First, a large amount of the highly reactive ozone produced by corona discharge in air could cause degradation of chromophores and polymer backbone. Another factor is variable humidity of ambient air and, consequently, uncertain concentration of predominant charge carrier $\left(\mathrm{H}_{2} \mathrm{O}\right)_{\mathrm{n}} \mathrm{H}^{+}$.

To realize repeatable poling process, the composition of discharge atmosphere should be controlled (e.g. for pure nitrogen gas). An additional benefit in the case of discharge in $\mathrm{N}_{2}$ is avoiding the production of highly reactive ozone. Since the corona initiation voltage and current are dependent on the temperature in discharge space the heat exchange between the heater/sample assembly and the discharge chamber should be prevented.

To obtain the second order nonlinear activity of polymeric materials a simple point/plane (two-electrode) technique of corona charging is successfully applied. At the same time, this simple technique not always provides information about the sample surface charge build-up and the efficiency of poling process. To study the dynamics of both the poling and the charge transport processes a three-electrode charging system - the corona triode - should be used. Introduction of a metal grid between the opposite electrode (with a thin polymeric sample film) and the corona electrode allows for control of the poling process.

In upcoming articles of this series, technical realization of both types of the corona discharge setups for poling the organic nonlinear optical polymers will be presented. Results of the quality tests of thin host-guest polymer film samples poled by the described setups will be presented and discussed as well.

\section{REFERENCES}

1. Dalton, L.R., Lao, D., Olbricht, B.C., Benight, S., Bale, D.H., Davies, J.A., Ewy, T., Hammond, S.R., \& Sullivan, P.A. (2010). Theory-inspired development of new nonlinear optical materials and their integration into silicon photonic circuits and devices. Optical Materials, 32, 658-668.

2. Comizolli, R.B. (1987). Uses of corona discharges in the semiconductor industry. $J$. Electrochem. Soc.: Solid-state science and technology, (February), 424-429.

3. Shahin, M.M. (1969). Appl. Opt. Suppl., (3), 106.

4. Shahin, M.M. (1969). Adv. Chem., 80, 48.

5. Chen, J., \& Davidson, J.H. (2002). Ozone production in the positive DC corona discharge: Model and comparison to experiments. Plasma Chemistry and Plasma Processing, 22 (4), 495-522.

6. Chen, J., \& Davidson, J. H. (2002). Electron density and energy distributions in the positive DC corona. Plasma Chemistry and Plasma Processing, 22 (2), June.

7. Cooperman, G. (1960). A theory for space-charge-limited current with application to electrical precipitation. Trans. Amer. Inst. Eng., Part I, 79, 47-50.

8. Knoessen, A. (2002). Photoisomerization in polymer films in the presence of electrostatic and optical fields. In " Photoreactive organic thin films", Sekkat Z. and Knoll N. (eds). Elsevier Science (USA), pp. 289-304.

9. Peek, F.W. (1929). Dielectric Phenomena in High-Voltage Engineering ( $3^{\text {rd }}$ ed-n). New-York: McGraw-Hill,

10. Morrow, R. (1997). The theory of positive glow corona. J. Phys., 30 (22), 3099-3114.

11. Raizer, Ju P. (1992). Phyzika gazovogo razrjada. Nauka, pp. 433-440. 
12. Kapcov, N.A. (1954). Elektronika. Nauka, pp. 371-384.

13. Cooperman, G. (1981). A new current-voltage relation for duct precipitators valid for low and high current densities. IEEE Transactions on industry applications, 1A-17, March/April, pp. 236-239.

14. Sigmond, R.S. (1982). Simple approximate treatment of unipolar space-chargedominated coronas: The Warburg law and the saturation current. J. Appl Phys., 53 (2), 891-898.

15. Mortazavi, M.A., Knoesen, A., \& Kowel S.T. (1989). Second-harmonic generation and absorption studies of polymer - dye films oriented by corona-onset poling at elevated temperatures. J. Opt. Soc. Am., B6 4, 733-741.

16. Wintle, H.J. (1992). Unipolar wire-to-plane corona: accuracy of simple approximations. Journal of Electrostatics, 28 (2), 149-159.

17. Knoessen, A., Molau, N.E., Yankelevich, D.R., Mortazavi, M.A., \& Dienes, A. (1992). Corona-poled nonlinear polymeric films: In situ electric field measurement, characterization and ultrashort-pulse applications. Int. J. of Nonlinear Optical Physics, 11 (1), pp. 73-102.

18. Bauer, S. (1996). Poled polymers for sensors and photonic applications. Appl. Phys., 80 (10), 5531-5558.

19. Sessler, G.M. (1987). Physical properties of electrets. Electrets, Springer-Verlag, Berlin 13

20. Suzuki, A., Matsuoka, Y., \& Ikushima, A.J. (1991). Substrate effect on process of nonlinear optical polymer films. Japanese Journal of Applied Physics Part 2 - Letters 30 8B 15 Aug.

21. Kazjar, F., \& Vitrant, G. (2003). Engeneering and application of functionalized polymers in nonlinear optics. Proc. SPIE Advanced Organic and Inorganic Optical Materials, 5122, 111-121.

22. Moreno, R.A., \& Gross, B. (1976). Measurement of potential buildup and decay, surface charge density, and charging currents of corona-charged polymer foil electrets. J. of Appl. Phys., 47 (8), 3397-3402.

23. Thomson, W., later Lord Kelvin (1898). Philos. Mag., 46, 82-120

24. Zisman, W.A. (1932). Rev. Sci. Instr., 3, 367-370

25. Vilitis, O., Fonavs, E., \& Muzikante, I. (2001). A system for measuring surface potential by the Kelvin-Zisman vibrating capacitor probe. Latv. J. Phys. Techn. Sci., (5), 38-56.

26. Gross, B., Giacometti, J.A., \& Leal Ferreira, G.F. (1981). Corona method for investigation of charge storage and transport in dielectrics. Annual Report of Conf. On Insul. And Diel. Phenomena, 39-44.

27. Fedosov, S.N., Sergeeva, A.E.,\& Giacometti, J.A. (1999). Pol. Liq. Cryst., 4017, 269.

28. Fedosov, S. N., \& Sergeeva, A. E. (2002). Corona poling of ferroelectric and nonlinear optical polymers. Moldavian J. of Phys. Sci., 2, 28-31.

29. Giacometti, J.A., \& Carvalho Campos, J.S. (1990). Constant current corona triode with grid voltage control. Application to polymer foil charging. Rev. Sci Instrum., 61 (3), $1143-1150$.

30. Giacometti, J.A. (1987). Radial current-density distributions and sample charge uniformity in a corona triode. J. Phys. D: Appl. Phys., 20, 675-682.

31. Dao, P.T., Williams, D.J., McKenna, W.P., \& Goppert-Baraducci, K. (1993). Constant current corona charging as a technique for poling organic nonlinear optical thin films and the effect of ambient gas. J. Appl. Phys., 73 (5) 1, 2043-2050.

32. Olivera, O.N., \& Jr., Leal Ferreira, G.F. (1985). Grid - to plate current-voltage characteristics of a corona triode. Rev. Sci. Instrum., 56 (10), 1957-1961.

33. Giacometti, J.A., \& Reggi, A.S. (1993). Thermal pulse study of the polarization distributions produced in polyvinylidene fluoride by corona poling at constant current. J. Appl. Phys., 74 (5), 3357-3365. 
34. Ribeiro, P.A., Raposo, M., Marat-Mendes, J.N., \& Giacometti, J.A. (1992). Constantcurrent corona charging of biaxially stretched PVDF films in humidity-controlled atmospheres. IEEE Transactions on Electrical Insulation, 27 (4), 744-750.

35. Giacometti, J.A., \& Oliveira, O.N.,Jr. (1992). Corona charging of polymers. IEEE Transactions on Electrical Insulation, 27 (5), 924-943.

36. Ren, W., Bauer, S., Yilmaz, S., Wirges, W., \& Gerhardt-Multhaupt, R. (1994). Optimized poling of nonlinear optical polymers based on dipole-orientation and dipolerelaxation studies. J. Appl. Phys., 75, 7211-7219.

37. Giacometti, J.A., Ribeiro, P.A., Raposo, M., Marat-Mendes, J.N., Carvalho Campos, J.S., \& DeReggi, A.S. (1995). Study of poling behavior of biaxially stretched poly(vinylidene fluoride) films using the constant-current corona triode. J. Appl. Phys., 78 (9), 5597-5603.

38. Giacometti, J.A., Fedosov, S., \& Costa M.M. (1999). Corona charging of polymers: Recent advances on constant current charging. Brazilian J. of Physics, 29 (2), 269-279.

39. Fedosov, S.N., Sergeeva, A.E., Giacometti, F.A., \& Polischuk S.G. (2002). Switching of polarization and relaxation phenomena in corona poled ferroelectric polymers. Physics and chemistry of Solid State, (3), 413-417.

40. Weinberg, Z.A., Matthies, D.L., Johnson W.C., \& Lampert M.A. (1975). Measurement of the steady-state potential difference across a thin insulating film in corona discharge. Rev. Sci. Instrum., 46 (2), 201-203.

\title{
HROMOFORU POLARIZĒĚŠNA PLĀNĀS ORGANISKO STIKLU KĀRTINĀS
} 1. KORONAS IZLĀDES IZMANTOŠANAS PĀRSKATS

\author{
O. Vilītis, E. Fonavs, M. Rutkis \\ Kopsavilkums
}

Pēdējos gados paaugstināta pētnieku uzmanība tiek pievērsta organisko molekulāro materiālu plašākai pielietošanai nelineārās optikas (NLO) ierīcēs. Starp tiem nozīmīgākie ir liela ātruma elektro-optiskie gaismas modulatori. Lai polimēru materiāls kḷūtu NLO aktīvs, polārās dalıs jāsakārto vienā virzienā ar ārējā elektriskā lauka palīdzību. Viena no iespējām, kā iegūt spēcīgu polarizējošu lauku, ir uzlādēt plānās kārtinas virsmu, izmantojot koronas izlādi. Šì raksta pirmā daḷa veltīta koronas izlādes fizikai, bet otrajā dạ̧ā ietverts plānu organisko kārtinu polarizēšanā lietojamo metožu un tehniku pārskats. Praktisko NLO polimeru polarizēšanu ar koronas izlādi gaisā stipri iespaido dažādā mitruma pakāpe un līdz ar to mainīgā dominējošo lādiņa nesēju $\left(\mathrm{H}_{2} \mathrm{O}\right)_{n} \mathrm{H}^{+}$koncentrācija. Lai realizētu atkārtojamu polarizēšanas procesu, ir jāstabilizē izlādes atmosfēras sastāvs, piemēram, izmantojot tīru slāpekḷa gāzi. Realizējot izlādi $\mathrm{N}_{2}$ atmosfērā, rodas iespēja atbrīvoties no ārkārtīgi reaktīvā ozona veidošanās. Vienkāršā punkta/plaknes koronas izlādes (divu elektrodu) tehnika ir pietiekama, lai panāktu polimeru materiāla otrās kārtas NLO aktivitāti. Tai pat laikā ar šo vienkāršo tehniku nav iespējams iegūt informāciju par parauga virsmas lādiṇa veidošanos un polarizēšanas procesa efektivitāti. Tālab, lai pētītu polarizēšanas un lādiņa pārneses procesus plānās kārtiņas virsmas uzlādei, ir nepieciešams izmantot trīs elektrodu sistēmu - koronas triodi.

11.01.2011. 